\title{
МЕДІАЛІНГВІСТИКА
}

Visn. Lviv. Univ., Ser. Zhurn. 2019: 46; 331-338 • DOI: http://dx.doi.org/10.30970/vjo.2019.46.10071

УДК 007: 304: 659

\section{ЕКСПЛІЦИТНІ ТА ІМПЛІЦИТНІ ВНУТРІШНЬОТЕКСТОВІ ЗВ'ЯЗКИ МІЖ ЧАСТИНАМИ РЕКЛАМНОГО ТЕКСТУ}

\author{
Любов М'яснянкіна \\ Львівський національний університет імені Івана Франка, \\ вул. Генерала Чупринки, 49, Львів, 79044, Украӥна, \\ e-mail:myasnyankina@gmail.com \\ https://orcid.org/0000-0002-7936-2025
}

Статтю присвячено аналізу внутрішньотекстових зв'язків між частинами рекламного тексту. Найпоширенішими є експліцитні засоби зв’язку, зокрема лексичний, граматичний та синонімічний типи повторів. Поширення імпліцитних засобів зв'язку пояснюють намаганням економії мовних засобів та необхідністю підвищення сприйняття тексту. Імпліцитність є засобом згортання текстових конструкцій.

Ключові слова: рекламний текст, еспліцитні засоби зв'язку, імпліцитні засоби зв'язку, лексичний повтор, синонімічний повтор, семантичний повтор, координатний зв'язок.

Рекламний дискурс є складним соціокультурним феноменом; він охоплює різні сфери життя сучасного соціуму і, таким чином, взаємодіє з різними видами людської діяльності. Вивчення рекламного дискурсу пов'язують як з теорією комунікації, так і $з$ теорією впливу. Але найбільше досліджень присвячено структурній організації рекламного тексту (Т.Волосожар, Х. Кафтаджієв, О. Медведєва, Т. Ліфшиць).

Рекламне повідомлення побудовано за стуруктурною схемою, що містить заголовок, зачин, основний текст, слоган, коду. Зазавичай виділяють кілька етапів впливу реклами на споживача: привернути увагу, викликати цікавість, змусити запам'ятати основну думку, навести аргументи на користь товару чи послуги. Спочатку реклама зацікавлює підсвідомо, за допомогою закликів і лексичних повторів, потім висуває ряд аргументів, які підтримують цікавість.

Однією з найважливіших категорій тексту, зокрема й рекламного, є зв'язність. Сигналами зв'язності є повтори, синоніми, тематичні групи слів. Виділяють такі показники зв'язності: сегментні, що об'єднують: 1) лексичні (повтори, синоніми, антоніми, однокореневі слова); 2) граматичні (сполучники, сполучні слова, ступені порівняння, вставні слова); 3) синтаксичні (порядок слів, частин, фрагментів); стилістичні (еліпсис, питальні речення, градація); суперсегментні (інтонація, пауза, наголос) та екстралінгвістичні (ситуація, асоціації) [ 5, С. 112].

(C) М'яснянкіна Л., 2019 
Т.А.Єщенко вважає, що категорія зв’язності виявляється у процесі структурування тексту, поєднання його частин та елементів. Вона розрізнює граматичну, семантичну, ономасіологічну, смислову, структурно-композиційну, референційну та прагматичну зв'язність [1, С.146 ].

Категорії зв’язності, цілісності рекламного тексту досліджували С.Волосожар, Н.Коваленко, О.Зелінська, І.Кочан. О.Зелінська наголошує: «Рекламний текст був і $\epsilon$ такою цілісною одиницею комунікації, якій властива завершеність внутрішньої та зовнішньої організації. Тобто він являє собою певну єдність лінгвальних та екстралінгвальних засобів, націлених на інформування та здійснення максимального психологічного впливу [3,С.9].

Мета статті - проаналізувати імпліцитні та експліцитні засоби зв’язку, що надають цілісності рекламному тексту.

Рекламний текст - це не хаотичне нагромадження одиниць різних мовних рівнів, а упорядкована система, в якій все взаємопов'язано та взаємообумовлено. Формальну зв'язність тексту називають когезією (В.Дресслер), зовнішньою спаяністю (В. Кожевнікова). Когезію у рекламному тексті можна втілити як експліцитно, так й імліцитно. Серед експліцитних засобів вираження найчастотнішим $є$ повтор, який передає додаткову інформацію, інтенсифікує емоційність мовлення, сприяє зв'язності та ритмізації мовлення, що підвищує вплив реклами на споживача. «Повтор це також багаторазове відтворення різних лінгвістичних одиниць: фонем, морфем, лексем, слів, словосполучень, речень. Причому повтори - це не лише засіб, а й необхідна умова (хоч і недостатня) зв'язності тексту. Вони беруть участь у горизонтальній і вертикальній зв'язності, сприяючи внутрішній цілісності» [4, С.37].

M. І. Ільченко, яка досліджувала повтор як реалізацію сугестивної стратегії навіювання адресату електорального дискурсу певних смислів, наголошує, що повтор «полягає в рекурентній експлікації «тематичних» концептів, які адресат актуалізує в дискурсі з метою реалізації спонукальних стратегій позитивної самопрезентації, солідарізації з народом або дискредитації опонента, збільшуючи ефективність сприйняття мовлення» [3, С.43]. За структурним критерієм М.Ільченко поділяє повтори на контактні (повторювання одиниць в кінці й на початку суміжних відтінків мовлення), анафоричні (повторювання початкових частин суміжних відрізків мовлення), епіфоричні (повторювання кінцевих елементів відрізків мовлення) та рамкові (адресат спочатку називає те, що вважає найбільш важливим, потім розгортає зміст повідомлення і як емоційно-оцінний підсумок повторює початкову пропозицію у кінці свого мовлення). За частиномовним критерієм М.Ільченко розрізняє простий лексичний повтор (елемент повтору не зазнає формальних змін), словотвірний (повторювані одиниці $є$ спільнокореневими),синонімічний (повторювані одиниці належать до одного синонімічного ряду) та граматичний, що поділено на займенниковий, сполучниковий та синтаксичний (повторення словосполучень або цілих предикацій).

Більшість дослідників розрізняють лексичний, граматичний, синонімічний та семантичний типи повторів.

У мові реклами найпоширенішими є традиційно граматичні, які виконують текстоутворювальну функцію. До таких засобів насамперед належать особові, присвійні та вказівні займенники. У друкованій рекламі якщо не друге, то третє, четверте речення пов'язане з попередніми за допомогою таких займенників. Наприклад: «Єшко» - відома міжнародна школа зі штаб-квартирою в Голландії. Її філії вже 
протягом кількох років успішно проводять освітню діяльність у багатьох європейських краӥнах; Протягом тисячоліть мед був єдиним доступним людині солодким продуктом. Його переваги оспівано в легендах Стародавньої Греиії, оповіданнях Біблії, сурах Корану. Він - божественний дар, щзо падає з неба разом з ранковою росою. Промед покрашує роботу репродуктивної системи, його можна застосовувати при гінекологічних захворюваннях, простатиті, аденомі. Він має протизапальні, протипухлинні й антибактеріальні властивості.

Сприяють цілісності реклами вказівні займенники, які відносяться до більшої частини тексту, пов'язують низку речень загальним змістом. Наприклад; Трапляється, щзо у вас немає часу, аби зачекати, коли праска охолоне. Для таких моментів компанія Philips створила термозахисну насадку, яка повністю закриває підошву праски, Це означає, щзо праску можна одразу прибрати на зберіганння без ризику пожежі.

Поширений засіб граматичного зв’язку - єдність виду й часу дієслів- присудків. При змалюванні явищ одного змістовного плану (характеристика товару, особи) дієслова-присудки звичайно виражені формами одного виду і часу. Копірайтери, характеризуючи товар чи послугу, використовують дієслова недоконаного виду теперішнього часу. Вживання таких дієслів дає змогу створити яскравий, неповторний образ об'єкта реклами; у споживача виникає враження, що він вже придбав те, про що йдеться в рекламі: Brillance - це перша стійка крем-фарба з Формулою колір Константа, шчо ідеально захищає інтенсивність кольору $і$ забезпечує до 25\% більше свіжості кольору. Для звабливих відтінків, щзо сяють так довго!

Вживання у всіх частинах рекламного дискурсу дієслів майбутнього часу не тільки пов'язує частини тексту, а й налаштовує споживача на те, що всі його мрії здійсняться: Ha всіх етапах придбання та використання віконних систем REHAU ви можете звернутися на інформаційну лінію, де знайдете допомогу в замовленні вікон, одержите консультацію експерта та рекомендації щуодо вибору надійного виробника вікон.

Дієслова минулого часу доконаного виду є засобом міжфразового зв'язку лише в рекламі-розповіді чи в рекламі, побудованій на контрасті: Дійсно, на Cxодi, де 5000 тому народився иеей духмяний напій, до нього ставилися як до справжньої дорогоизіності, а хоробрі воїни отримували глечик чаю як винагороду за надзвичайні вчинки і збирали рідних та друзів, щзоб розділити з ними иеей чудовий дар. Можливо, саме з изього почалася традиція чайних изеремоній.

Найпоширенішим експліцитним засобом зв'язку є повторення слів, висловів, які можуть відрізнятися за певними формальними ознаками. До таких слів належать здебільшого власні іменники, що є назвами товару чи фірми. Ця назва функціонує в рекламному заголовку чи слогані, а потім неодноразово повторюється в рекламному тексті. Порівн.: Тільки ЛІНЕКС містить три види найбільш корисних бактерій, які природним чином відновлюють нормальну роботу кішківника. Саме тому ЛІНЕКС ретельно лікує дисбактеріоз та попереджує його прояви в майбутному. ЛІНЕКС лікує дисбактеріз та усуває його наслідки - кишкові розлади. ЛІНЕКС. Революція в животі відміняється!; Ніжна, немов дотик квітки, прокладка Naturella містить крем-бальзам з ромашкою. Naturella - захист, щзо також доглядає твою шкіру.

За словотвірного повтору зв'язок між частинами рекламного тексту втілено за допомогою слів, що входять до однієї словотвірної парадигми: Розвиток сучасної 
медищини відкриває нові можливості в лікуванні геморою. Небагато людей знають, щзо є вже інші засоби, крім операції, щзоб вилікувати ичю прикру хворобу. Для повноиінного лікування, а також для запобігання рецидиву, необхідно відвідати лікаря декілька разів (лікар - лікування - вилікувати).

Запам'ятовується реклама, в якій однокореневі слова виконують функцію контекстуальних антонімів: Тільки Есениіале - високоефективний препарат, щзо містить фосфоліцин, насправді виліковує, а не заліковує печінку і відновлює ї̈ на клітинному рівні.

Найбільш ефективний засіб лексичного повтору синонімічний. Кожний новий зворот, що замінює лексичний повтор, додає нову рису до характеристики об'єкта реклами. Порівн.: Чай з присмаком весни. Ми вітаємо вас з настанням тепла $і$ бажаємо квітучої вроди, міцного здоров'я і приємного чаювання разом з чорним чаєм «Принцеса Нурі» Високогірний. Сподіваємося, щзо ичей цілющий напій перетворить на свято будь-яке ваше застілля. А щуе цей чай, вирощений під самими хмарами, на висоті 2500 метрів над рівнем моря, може входити до складу незвичних коктейлів.

Об’єктом реклами є чай «Принцеса Нурі». Але починається реклама з образного вислову «чай з ароматом весни». Образні вислови, вжиті в межах невеликого тексту (цілющій напій; чай, вирощений під самими хмарами), дають змогу не тільки поєднати частини тексту, а й викликати захоплення чудовим напоєм.

Більш вдалий прийом - вживання на початку рекламного тексту синонімів до об’єкта реклами, потім назви товару і знову заміна її на синонім: «Божа роса» кольору невинності. Молоко «Галичина» - це чудодійний життєвий еліксир, який поєднує в собі иілющу силу альпійських лугів та турботу людей, щзо живуть у гармонії з природою та власним серцем. Маючи в собі величезну вітамінну скарбницю, молоко «Галичина» є незамінним в щзоденному раціоні тих, хто хоче мати непохитне здоров'я i випромінювати життєрадісність. Про людей, які п’ють изей чудодійний еліксир, можна сказати, що вони обрані силою природи і збагачені нею ж. Галичина. Життя серед вічних изінностей.

В основу цього тексту покладено такий синонімічний ряд: «божа роса» - молоко «Галичина» - чудодійний життєвий еліксир - цілюща сила альпійських лугів вітамінна скарбниця - вічна цінність.

Більшість копірайтерів починають рекламний текст з назви товару i, тільки переконавшись, що реклама асоціюється у споживача саме з цією назвою, добирають до неї синоніми: Кухонний комбайн BOSCH - не лише надійний універсальний та потужний помічник дбайливої господині. Він може слугувати унікальною прикрасою будь-якої кухні - незалежно від стилю та уподобань. Найпомітніша ззовні принада цьього унікального агрегату - чаша з нержавіючої сталі, яка замінює традиційну пластикову. Додайте до изього «космічну» сріблясту панель, світлодіодні індикатори режимів роботи - $і$ ви одразу зрозумієте: для изього комбайна треба шукати найпомітніше та найпочесніше місие на кухні.

У тексті створено синонімічний ряд, що містить чотири компоненти: кухонний комбайн BOSCH, надійний, універсальний та потужний помічник дбайливої господині, унікальна прикраса будь-якої кухні, унікальний агрегат. Домінантою цього ряду є назва товару, яка знайщла відображення у рекламному слогані: BOSCH. Buнаходження для життя. 
Семантичний повтор поєднує ознаки експліцитного та імпліцитного засобів зв’язку. Копірайтер вживає у тексті слова, що є компонентами того семантичного поля, до якого належить й ключове слово. Ключове слово, назва якого повторює назву семантичного поля, вжите у слогані чи у заголовку. Слова, що належать до цього семантичного поля, повертають нас до заголовка і пов'язують між собою частини тексту. Наприклад: Мульти-табс Актив - додай енергії. Сучасний спосіб життя ставить підвищені вимоги до стану здоров'я. Доволі часто доводиться боротися $з$ навантаженнями та стресами і при иьому залишатися в хорошій формі. Багатьом з нас необхідна додаткова енергія. Ось чому новий Мульти-табс Актив містить максимальну дозу женьшеню. Женьшень має адаптогенний ефект, покрамує енергетичний обмін, підвищує фізичну та розумову працездатність. Вітаміни і мінерали, що входять до складу Мультитабс Актив, допомагають організмові долати стреси та навантаження, зміџнюють імунітет і дають ще більше енергії для життя!

Більшість слів, вжитих у цьому рекламному тексті, тяжіють до семантичного поля «енергія»: здоров'я, хороша форма, фізична та розумова працездатність, імунітет, зміцнюють, адаптогенний ефект. Ключове слово енергія збігається з назвою семантичного поля; вживання його в заголовку дає змогу якнайтісніше пов'язати семантику заголовка з семантикою рекламного тексту.

Ефективний засіб міжфразового зв’язку - належність компонентів реклами до різних семантичних полів, які у тексті протиставлено.Так, тексти , в яких рекламують медичні препарати і послуги, побудовані на протиставленні понять «здоров'я» - «хвороба». 3 хворобою асоціюються такі слова, як неприємний, скаржитися, проблеми, поганий, стреси, млявий, нездатний тощо; зі здоров’ям - активізувати, відновлювати, нормальний, благотворний, комфортний, повноцінний тощо. В оральній рекламі (рекламі різноманітних страв, кондитерських виробів) протиставлено поняття «смачний»- «несмачний», «корисний»- «некорисний»; в анальній рекламі (реклама засобів для підтримання чистоти) протиставлено поняття «чистий» - «брудний»; у рекламі для нарцисів (реклама модного одягу, парфумів, кремів) протиставлено поняття «красивий»- «некрасивий».

Слова 3 негативною оцінністю протиставлено словам з позитивною оцінністю. Зісталення слів, протилежних за семантикою, поєднує частини тексту,сприяє його цілісності. Наприклад: Вам набридли гучні промови та марні обіиянки?! Ви здатні на більше?! Це для Вас! Ми допоможемо Вам засвоїти нові професії, реалізувати свої плани, зайнятися виробництвом і менеджментом. Ми навчимо Вас заробляти! Укладання угод, робота з клієнтом, доставка замовлень, складські операиії та ще більше напрямів. Зроби своє майбутнє сам!

У цьому тексті протиставлено ключові прикметники «марний» та «новий». Менша частина слів пов'язана з семантичним полем «минуле» (набридли, гучні, марні) і має негативне забарвлення. Більша ж частина мовних одиниць пов'язана зі семантичним полем «майбутнє» і $€$ позитивно оцінною (нові, реалізувати, заробляти).

Компоненти реклами можуть належати до різних семантичних полів, але ці поля доповнюють одио одне, що дає змогу не тільки пов’язати частини тексту, а й подати всебічну характеристику об'єкта реклами. Іноді засобом поєднання частин тексту $є$ протиставленість слів з позитивною оцінністю. Частині лексем, що є компонентами рекламного тексту, притаманна гедоністична оцінність (те що подобається: приємний, смачний, привабливий, запашний, духмяний); інша група слів пов’яза- 
на $з$ практичною діяльністю людини, дає раціоналістичну оцінку об’єкта реклами. Слова, що дають сенсорну оцінку товарів чи послуг, вживають у рекламі парфумів, харчових продуктів, одягу. Утилітарні оцінки поширені в текстах, об'єктом яких є побутова техніка, медичні препарати. Поєднання різних оцінок в тексті дає змогу всебічно схарактеризувати об'єкт реклами; це активізує увагу споживача і сприяє цілісності рекламного тексту. Наприклад: Користь від молока... Що може тішити маму більше, ніж здорова дитина? Тільки здорова та весела дитина! 3 кожним днем організм малюка потребує більше енергії та корисних речовин. В природі існує тільки один повноцінний продукт, в якому містяться всі необхідні для дітей речовини у найкращчому для засвоєння поєднанні - цุе молоко. Молоко означає кращчий апетит та гарний настрій, а щзо особливо важливо - міияний імунітет.

Але як переконати свого першокласника випити щзе трішечки молока? Можна, звичайно, розповісти йому, щчо денна дитяча норма кальцію та вітамінів міститься у трьох склянках иъього напію. Але слово «смачно» малюки розуміють набагато краще, ніж «корисно. Саме тому мами у всьому світі довіряють Nesquik: адже він має чудовий шоколадний смак, щуо так подобається дітям, поєднує в собі корисні можливості молока і какао, а також збагачений вітамінами. Вітаміни, які містить Nesquik, необхідні для повноцінного розвитку підростаючого організму, калорії знадобляться для шцоденного активного життя вашого малюка, а шоколадний смакперевірений засіб для хорошого настрою!

Такі лексеми, як енергія, калорії, повноцінний, необхідний, кращий, гарний, міцний тяжіє до семантичного поля «корисний». Їм притаманна раціоналістична оцінка. Менша частина слів (чудовий, шоколадний,смачний, хороший) має сенсорну оцінку, належить до семантичного поля «смачний». У рекламі ці слова взаємодіють, доповнюють семантичну структуру одне одного. Ця взаємодія знаходить відображення у рекламному слогані: Якби все корисне було б таким смачним, як Nesquik!

Семантичні повтори поєднують ознаки експліцитного та імпліцитного засобів зв’язку.Однак у рекламному тексті поширюються й імпліцитні засоби внутрішньотекстового зв'язку, що пояснюють двома причинами: намаганням економії мовних засобів та необхідністю підвищення сприйняття тексту. Т.Сщенко наголошує, що в тексті існують імпліцитні (приховані) зв’язки. не виражені вербально. «Пропущеними можуть бути певні члени речення (граматична імпліцитність), речення, частини речень (семантична імпліцитність). Імпліцитність є засобом згортання текстових конструкцій, яку використовують здебільшого для економії мовних засобів» [1, С.148].

Бажання економії мовних засобів зумовлює елімінацію експліцитно поданих засобів внутрішньотекстових зв'язків, тобто сприяє виникненню імліцитного змісту. Порівн.: Увага! Активне сонце шкідливе для Ваших очей. Сонцезахисні контактні лінзи.

Пропущено поєднувальні компоненти між другим і третім реченням, та це активізує увагу читача, дає йому змогу самостійно встановлювати зв'язок між цими реченнями. Пошуку інформації сприяє порядок розташування частин речень та наявність експліцитно поданих компонентів внутрішньотекстового зв'язку (сонце сонцезахисний). Вербалізація пропущеного компонента дає змогу виявити зв'язок між фактами дійсності, про які йдеться в цих реченнях. Одне із можливих рішень: Сонцезахисні контактні лінзи врятують Вас від шкідливих сонячних променів. Але 
це не єдине рішення, можливі інші: Сонцезахисні контактні лінзи є в продажу; Купуйте сонцезахисні контактні лінзи.

Більшість рекламних текстів розраховано на мимовільну увагу споживачів, тому оформлення та зміст рекламного тексту повинні зацікавити та утримувати увагу потенційного споживача. Для цього використовують різноманітні графічні засоби, значки, що виділяють початок кожного значущого фрагменту інформації. Намагання полегшими сприйнятття тексту призводить до порушення різних типів когезії. Але це протиріччя можна вирішити шляхом імплікації деяких типів зв'язку. Принцип кращого та легшого сприйняття тексту реклами стає основною причиною поширення в рекламному дискурсі імпліцитних внутрішньотекстових зв'язків.

Т. Лівшиць вважає, що одним із специфічних засобів імпліцитного внутрішньотекстового зв'язку є координатний зв'язок. Суть його полягає в тому, що як перше речення в рекламі використовують номінативне речення і співвідносять 3 ним наступні речення, що наводять рекламні аргументи. Замість багаторазового повтору відбувається співвіднесеність (координація) кожного наступного речення з першим, яке містить назву товару чи послуги.

Ехіначея-ратіофарм

- периий в Украӥні препарат Ехінацеї у формі таблеток

- позитивний вплив на очищення судин на капілярному рівні, що пришвидщує кровопостачання

- відновлення коронарного та мозгового кровообігу

- сприяння зменшенню набряків кінцівок.

Назва об'єкта реклами в сильній позиції стає компонентом, що пов’язує всі частини тексту. Координатний зв'язок постійно використовують в рекламних текстах, тому що це дає змогу зафіксувати увагу на об'єкті реклами через необхідність ретроспективного звернення до назви товару, сприйняття кожного наступного аргумента на користь того, що рекламують. Кожний аргумент виділено графічно, що дає змогу оцінити переваги товару.

Таким чином, структура рекламного тексту містить експліцитні та імпліцитні плани. Експліцитні зв’язки передано вербально, за допомогою різноманітних типів повтору. Імпліцитні зв'язки - це мисленнєва операція, яка поєднує вербальні та невербальні складові тексту. Ці зв'язки актуалізуються за допомогою підтексту та авторської інтенції.

Серед експліцитних засобів зв'язку поширені повтори різного типу. Але специфічною ознакою рекламного дискурсу треба визнати різноманітні види імпліцитних зв’язків, що пояснюємо тенденцією до економії мовних засобів, а також намаганням підвищити сприйнятття тексту. Специфічним засобом $є$ координатний зв'язок, що відновлює пропущені частини тексту.

\section{REFERENCES}

1. Сщенко Т. А. Лінгвістичний аналіз тексту: навч. посіб./ Т. А. Єщенко. К.: ВЦ «Академія», 2009. 264 с.

2. Зелінська О. І. Лінгвальна характеристика українського рекламного тексту. Автореф. дис. канд. філол. наук. 10.02.01 / О.І. Зелінська. Харків: Державний пед. ун-т імені Г.С. Сковороди. Х.,2002. 17 с. 
3. Ільченко М. Л. Повтор як втілення сугестивної стратегії англомовного електорального дискурсу / М. Л. Ільченко // Вісник Харківського національного ун-ту ім. В. К. Каразіна. Серія Романо-германська філологія. Методика викладання іноземних мов: Х.: ХНУ ім. В. Каразіна. 2010. С. 42-47.

4. Кочан I. М.Лінгвістичний аналіз тексту: навч. посіб. / I. М. Кочан. К.: Знання, 2008. $423 \mathrm{c}$.

5. Селіванова О. О. Актуальні напрями сучасної лінгвістики (аналітичний огляд) / О. О. Селіванова. К.: Видавництво Українського фотосоціологічного центру, 1999. $148 \mathrm{c}$.

\title{
EXPLICIT AND IMPLICIT INTERTEXTUAL LINKS BETWEEN PARTS OF THE ADVERTISEMENT TEXT
}

\author{
Lubov Myasnyankina \\ Ivan Franko National University of Lviv, \\ Generala Chuprynky Str., 49, 79044, Lviv, Ukraine \\ e-mail: myasnyankina@gmail.com \\ https://orcid.org/0000-0002-7936-2025
}

Advertising text is not a chaotic accumulation of units of different language levels, but an ordered system in which everything is interconnected. The formal connectivity in the advertising text can be implemented both explicit and impartially. Among the explicit means of expression of cohesion, the most frequent is the repetition that transmits an additional information, intensities the emotionally of speech, promotes connectivity of speech, which increases the impact of advertising of consumer.

The repetition is the accumulation of the same type of language units within the text. The explication of thematic positively, which the addressee actualizes in the discussion with the aim of implementing incentive strategies for positive self presentation of discrediting the opponent. Increasing the efficiency of speech perception.

Most researchers distinguish lexical, grammatical and semantic types of repetitions. All these types of repetitions are traditionally used in a advertising discourse. The lexical repetition is divided into a simple one, word-building and synonymous.

The semantic repetition combines signs of an explicit and implicit connection. We explain the spread of implicit means of communication for two reasons an effect to save languages resources and need to increase the perception of the text. Specific means of implicit are coordinate communication. The explicit connections are transmitted verbally, implicit communications are a thought-based operation the combines verbal and non-verbal components of the text.

Key words: advertising text, explicit communication means, implicit means of communication, lexical repeat, synonym repeat, semantic repeat, coordinate communication. 